\title{
Evaluation of hepatic fibrosis in HIV/HCV co-infected individuals in Yaoundé, Cameroon: usefulness of APRI score in resource-constrained settings
}

Rodolphe Dobseu ${ }^{1,2}$, Aubin Nanfack ${ }^{1,3^{*}}$ D, Mathurin Kowo ${ }^{4}$, Georgia Ambada', Rachel Kamgaing ${ }^{1}$, Collins Chenwi ${ }^{1,3}$, Nadine Fainguem ${ }^{1,5}$, Aude Ka'e ${ }^{1}$, Eric Ngangoum² ${ }^{2}$ Samuel Sosso ${ }^{1}$, Clergé Tchiegang ${ }^{2}$ and Alexis Ndjolo ${ }^{1,3}$

\begin{abstract}
Background: HIV infection exacerbates the prognosis of HCV infection, with a faster progression of hepatitis. Hepatic fibrosis is the major disruption of the hepatic tissue architecture characterized by anarchic deposition and excess of the extracellular matrix. The objective of this study was to evaluate hepatic fibrosis in HIV/HCV co-infected individuals as compared to HCV mono-infected.

Methods: A total of 97 participants (mean age $60.2 \pm 14.3$ years and 0.76 male/female sex ratio) was enrolled in a study conducted in Yaoundé, Cameroon from November 2018 to January 2019. Liver fibrosis was assessed by the APRI score (Aspartate Aminotransferase or AST/Platelet Ratio Index) which identifies the stage of fibrosis as classified by the Metavir system (F0 to F4). CD4 counts and plasmatic HIV viral load of HIV/HCV co-infected individuals were determined and the correlation between hepatic fibrosis and immuno-virological status established. Statistical analysis was done using Microsoft Excel 2016 and Epilnfo7 software.

Results: A high proportion (63.6\%) of HIV/HCV co-infected participants had an abnormal AST level: 73.6 $\pm 45.8 \mathrm{IU} / \mathrm{L}$ as compared to $58.5 \pm 39.3 \mathrm{IU} / \mathrm{L}$ (59.3\%) among HCV mono-infected participants. The frequency of thrombocytopenia was 63.6\% with a mean platelet count of $137 \pm 50 \times 10^{3} \mathrm{IU} / \mathrm{L}$ in HIV/HCV co-infected participants as compared to $176 \pm 67 \times 10^{3} \mathrm{IU} / \mathrm{L}$ in HCV monoinfected participants (38.4\%). The progression of hepatic fibrosis in participants with clinically significant fibrosis: F2, F3 and F4 was higher among HIV/HCV co-infected and the mean APRI score was $1.7 \pm 1.4$ versus $1 \pm 0.8$ among HCV mono-infected (26.7\%). All participants (100\%) with detectable HV viral load had clinically significant fibrosis compared to $33.4 \%$ in those with undetectable HIV viral load $(p=0.55)$. Only $42.9 \%$ participants with CD4 > 500 cells $/ \mu \mathrm{L}$ had clinically significant fibrosis $(p=0.72)$ while $100 \%$ participants with CD4 $<200$ cells/ $\mu \mathrm{L}$ had clinically significant fibrosis $(p=0.58)$.
\end{abstract}

Conclusions: A high level of AST combined with thrombocytopenia (APRI score > 1.5) is an indicator of hepatic fibrosis in HIV/ $\mathrm{HCV}$ co-infected individuals. Because of its non-invasive and less costly nature, the APRI score can be a suitable biomarker to monitor hepatic fibrosis in HIV/HCV co-infected individuals in resource constrained settings.

Keywords: HIV/HCV co-infection, Liver fibrosis, APRI score, Thrombocytopenia, Resource constrained settings

\footnotetext{
* Correspondence: a_nanfack@yahoo.fr

1"Chantal Biya" International Reference Centre (CIRCB) for research on HIV/

AIDS prevention and management, P.O. Box 3077, Yaoundé, Cameroon

${ }^{3}$ University of Yaoundé I, Faculty of Medicine and Biomedical Sciences

(FMSB), Yaoundé, Cameroon

Full list of author information is available at the end of the article
}

(c) The Author(s). 2020 Open Access This article is licensed under a Creative Commons Attribution 4.0 International License, which permits use, sharing, adaptation, distribution and reproduction in any medium or format, as long as you give appropriate credit to the original author(s) and the source, provide a link to the Creative Commons licence, and indicate if changes were made. The images or other third party material in this article are included in the article's Creative Commons licence, unless indicated otherwise in a credit line to the material. If material is not included in the article's Creative Commons licence and your intended use is not permitted by statutory regulation or exceeds the permitted use, you will need to obtain permission directly from the copyright holder. To view a copy of this licence, visit http://creativecommons.org/licenses/by/4.0/ The Creative Commons Public Domain Dedication waiver (http://creativecommons.org/publicdomain/zero/1.0/) applies to the data made available in this article, unless otherwise stated in a credit line to the data. 


\section{Background}

Hepatitis C Virus (HCV) and Human Immunodeficiency Virus (HIV) infections are serious public health problems worldwide due to their high prevalence. In 2019, UNAIDS estimated that 37.9 million people worldwide were living with HIV (PLWHIV) [1]. Sub-Saharan Africa remains the most affected area with more than $70 \%$ of the world's people affected [2]. About 3 to 4 million people are newly infected with $\mathrm{HCV}$ each year worldwide resulting in 71 million people with chronic infection, with nearly 400,000 deaths per year [3]. Although the available data is limited, it appears that $\mathrm{HCV}$ prevalence and mortality rates vary considerably across regions. Africa is the second most endemic area for HCV after the Middle East with an estimated prevalence of 3.2\% [4]. HCV infection is widespread among HIV-infected populations because these two viruses share the same transmission routes (parenteral, sexual and mother-to-child). In a recent meta-analysis, approximately $2,278,400$ individuals worldwide were co-infected with $\mathrm{HIV} / \mathrm{HCV}$, representing a prevalence of $6.1 \%$ of people infected with HIV [5].

Since the advent of Highly Active Antiretroviral Therapy (HAART) in 1996, HIV infection has become a chronic disease, with an increase in the life expectancy of HIV-infected individuals worldwide; from 1.2 million deaths in 2010 to 770,000 in 2019 representing a reduction of 33\% since 2010 [1]. On the other hand, the quality of life and survival of people living with HIV are threatened by opportunistic infections among which the relatively frequent occurrence of chronic hepatitis $C$ and the risks of hepatotoxicity under Antiretroviral Therapy (ART), leading to transaminase levels up to ten times higher than normal. Very often, the evolution of this chronic hepatitis $\mathrm{C}$ progresses to the stage of severe liver fibrosis, cirrhosis and Hepatocellular Carcinoma [6]. The prevention of the progression of chronic hepatitis $\mathrm{C}$ requires early diagnosis of hepatic fibrosis. Fibrosis, the consequence of the fibrogenesis process, is the major perturbation of the architecture of the hepatic tissue characterized by an uncontrolled and excessive deposition of the extracellular matrix. Although the mechanisms by which HIV and $\mathrm{HCV}$ interact to influence the progression of liver disease are not well understood, it has been reported that HIV infection increases HCV viremia by 2 to 8 times resulting in a decrease in spontaneous recovery from acute hepatitis. Secondly, HIV/HCV co-infection is responsible for increasing the risk of mother-to-child and sexual transmission of HIV and HCV (3 to $20 \%$ and 0 to $3 \%$, respectively). Finally, HIV/HCV co-infection aggravates the histological course of $\mathrm{HCV}$ infection by accelerating the onset of hepatic fibrosis due to $\mathrm{HCV}$ [7].

In Cameroon, studies have estimated $\mathrm{HCV}$ prevalence between 1 and 13\% [6] while HIV prevalence is 3.4\% [8]. These data suggest that estimates of the prevalence of co-infection may vary depending on the study population and geographical area. Liver toxicity increases with multiple pharmacokinetic interactions in $\mathrm{HIV} / \mathrm{HCV}$ coinfection, and low risk of $\mathrm{HCV}$ eradication continue to be a challenge for monitoring the rapid onset of liver fibrosis in $\mathrm{HIV} / \mathrm{HCV}$ co-infected individuals as compared to $\mathrm{HCV}$ mono-infected. Indeed, mortality from liver disease remains even higher among $\mathrm{HIV} / \mathrm{HCV}$ co-infected individuals than among HIV or HCV mono-infected individuals [9]. Since HCV screening and surveillance of people living with HIV (PLWHIV) is not systematic, there is little data in our context on the assessment of liver disease in HIV/ HCV co-infection. However, the liver, in addition to being the target organ of HCV, hepatotoxic substances (drugs, alcohol), tumor and infectious manifestations, can also be the target organ of HIV [10]. This assessment should be systematic to prevent the progression of liver disease and initiate appropriate management. The objective of this study was to evaluate hepatic fibrosis in $\mathrm{HIV} / \mathrm{HCV}$ coinfected participants as compared to HCV mono-infected using APRI score; In addition, we also evaluated the effect of HIV viremia and CD4 count on the occurrence of hepatic fibrosis in HIV/HCV co-infected participants.

\section{Methods \\ Study design and setting}

A cross-sectional and descriptive study to evaluate hepatic fibrosis in 97 participants followed at the Yaoundé University Teaching Hospital (CHUY) and the "Chantal Biya" International Reference Center (CIRCB) was conducted from November 2018 to January 2019. Participants included in this study were: (a) people with $\mathrm{HCV}$ chronic infection (presence of HCV-RNA 6 months after first diagnosis), (b) having given their consent, and (c) over 21 years of age. Socio-demographics were recorded using a questionnaire. Of note, all HIV infected participants were on antiretroviral therapy.

\section{Determination of AST level}

The AST level was determined by spectrophotometry with the BT 3000 Plus equipment (Biotechnica Instruments, Rome-Italy) using the quantitative analytical method which consists in measuring the optical density of a given chemical substance generally in solution. The optical density of the samples is determined by a spectrophotometer previously calibrated over the absorption wavelength of the substance to be studied.

\section{Platelet count analysis}

Platelet count was determined through full blood count testing with the Sysmex XN 1000 analyzer (Sysmex Corporation, Kobe-Japan) which allows the analysis of levels and the identification of human blood components by flow cytometry. 


\section{Evaluation of hepatic fibrosis}

The evaluation of hepatic fibrosis was determined using the APRI score (Aminotransferase divided by Platelet Ratio Index), which is a non-invasive technique that measures blood parameters (indirect markers of fibrosis such as AST and platelet count) [11]. Hepatic fibrosis was classified using the Metavir system on a scale of F0 to $\mathrm{F} 4$ ( $\mathrm{F} 0=$ no fibrosis, $\mathrm{F} 1=$ minimal fibrosis, $\mathrm{F} 2=\bmod -$ erate fibrosis, F3 = severe fibrosis, F4= cirrhosis) [12]. Fibrosis was considered clinically significant at the F2, F3 and F4 stages.

\section{CD4 analysis and quantification of HIV viral load}

CD4 lymphocyte count was determined by flow cytometry using the CyFlow Counter (Sysmex Corporation, Kobe-Japan) which allows quantitative and qualitative analysis through identification and counting of $\mathrm{CD} 4^{+} \mathrm{T}$ lymphocytes according to the manufacturer's instruction. The quantification of HIV viral load was determined by real-time PCR on the Abbott m2000rt platform (Abbott RealTime HIV-1, France) which is a quantification technique that allows the formation of amplified products to be monitored in real time, cycle by cycle, using fluorescent probes that are hybridized and activated simultaneously with amplification [13].

\section{Statistical analyses}

Statistical analyses were done using Microsoft Excel 2016 and EpiInfo7 software. The correlation coefficient established the relationship between hepatic fibrosis and the immuno-virological status of the participants in this study. Multivariate analyses were used to assess the association between the dependent (APRI score) and independent variables (sex, age, viral load and CD4 cell count). A significant value was considered at $P<0.05$.

\section{Results}

Characteristics of the study population

A total of 97 participants $(11 \mathrm{HIV} / \mathrm{HCV}$ co-infected and $86 \mathrm{HCV}$ mono-infected) were enrolled for this study. Most of the participants (57\%) were female and the mean age of the study population was 60.2 years (IQR: 21-85) as detailed in Table 1 . The mean AST was $60.3 \pm 40.1 \mathrm{IU} / \mathrm{L}$ [7 to 259 ] ranging from $73.6 \pm 45.8 \mathrm{IU} / \mathrm{L}$ [26 to 179] in HIV/HCV co-infected participants to $58.5 \pm 39.3 \mathrm{IU} / \mathrm{L}$ [7-259] in HCV mono-infected. The mean platelet was $172 \pm 67 \times 10^{3} \mathrm{IU} / \mathrm{L}$ [50 to $369 \times 10^{3}$ ] ranging from $138 \pm 50 \times 10^{3} \mathrm{IU} / \mathrm{L}$ [ 57 to $227 \times 10^{3} \mathrm{IU} / \mathrm{L}$ ] in $\mathrm{HIV} / \mathrm{HCV}$ co-infected participants to $176 \pm 68 \times 10^{3}$ IU/L [50 to $369 \times 10^{3} \mathrm{IU} / \mathrm{L}$ ] in HCV mono-infected. The incidence of thrombocytopenia in HIV/HCV co-infected participants was $63.6 \%$ compared to $38.4 \%$ in $\mathrm{HCV}$ mono-infected (see Table 1).

\section{Evaluation of hepatic fibrosis outcomes}

The mean APRI score in this study was $1.1 \pm 0.9[0,1$ à 5,4]. The mean APRI score for $\mathrm{HIV} / \mathrm{HCV}$ co-infected participants was $1.7 \pm 1.4$ [0.4 to 5.4] and the frequency of participants with clinically significant fibrosis (F2, F3 and F4) per the Metavir classification was $63.6 \%$ (95\% $\mathrm{CI})$. The mean APRI score for HCV mono-infected participants was $1 \pm 0.8$ [0.1 to 3.6] and the frequency of participants with clinically significant fibrosis was $39.5 \%$ (95\% CI). Figure 1 shows the distribution of the study population by stage of hepatic fibrosis and Fig. 2, the distribution of hepatic fibrosis stage by gender.

\section{Effect of HIV viremia on the progression of hepatic fibrosis}

All HIV/HCV co-infected participants were on antiretroviral therapy and six (54.5\%) had an undetectable HIV plasmatic viral load $(<40$ copies $/ \mathrm{mL})$. All participants

Table 1 Demographic and clinical characteristics of the study population

\begin{tabular}{|c|c|c|c|}
\hline Variable & $\begin{array}{l}\text { Study Population } \\
N=97\end{array}$ & $\begin{array}{l}\mathrm{HIV} / \mathrm{HCV} \\
N=11\end{array}$ & $\begin{array}{l}\mathrm{HCV} \\
N=86\end{array}$ \\
\hline \multicolumn{4}{|l|}{ Gender n (\%) } \\
\hline Female & $55(57)$ & $07(64)$ & $48(56)$ \\
\hline Male & $42(43)$ & $04(36)$ & $38(44)$ \\
\hline Mean age in years & 60.2 & 58.9 & 60.4 \\
\hline Mean AST (UI/L) & $60.3(7-259)$ & $73.6(26-179)$ & $58.5(07-259)$ \\
\hline Mean platelet $\times 10^{3}(\mathrm{UI} / \mathrm{L})$ & $172(50-369)$ & $138(57-227)$ & $177(50-369)$ \\
\hline Mean APRI score & $1.1(0.1-5.4)$ & $1.7(0.4-5.4)$ & $1(0.1-3.6)$ \\
\hline Stage F0 n (\%) & $36(37.1 \%)$ & $03(27.3 \%)$ & $33(38.4 \%)$ \\
\hline Stage F1 n (\%) & $20(20.6 \%)$ & $01(09.1 \%)$ & $19(22.1 \%)$ \\
\hline Stage F2 n (\%) & $11(11.3 \%)$ & $00(0.0 \%)$ & $11(12.8 \%)$ \\
\hline Stage F3 n (\%) & $13(13.4 \%)$ & $04(36.3 \%)$ & $9(10.5 \%)$ \\
\hline Stage F4 n (\%) & $17(17.5 \%)$ & $03(27.3 \%)$ & $14(16.2 \%)$ \\
\hline
\end{tabular}




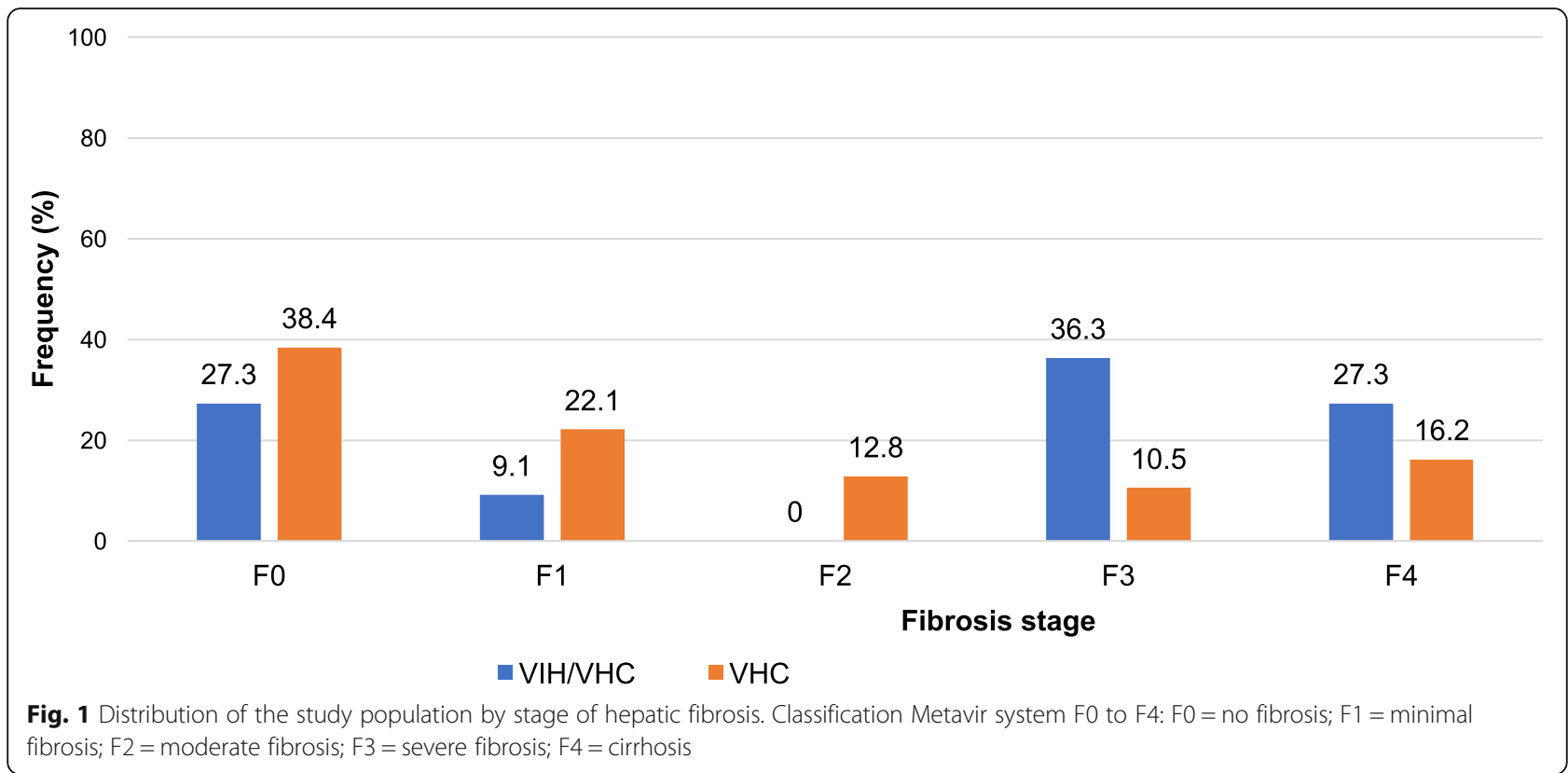

with detectable HIV viral load ( $\geq 40$ copies $/ \mathrm{mL}$ ) had clinically significant fibrosis. Two (33.3\%) participants with undetectable HIV plasmatic viral load had clinically significant fibrosis (Table 2).

\section{Effect of CD4 count on APRI score}

The median CD4 count in this study was 536 cells $/ \mu \mathrm{L}$ [106-875; IQR:169-709]. All participants with CD4 count $<200$ cells $/ \mu \mathrm{L}$ had clinically significant fibrosis. Three (42.86\%) participants with CD4 > 500 cells $/ \mu \mathrm{L}$ also had clinically significant fibrosis as shown in Table 3.

\section{Predictors of the progression of hepatic fibrosis}

Multivariate analysis considering HIV viral load, CD4 cell count, gender and age of participant's, revealed that these factors were independently associated with the occurrence of hepatic fibrosis in the participants of this study. In participants over 60 years of age, the incidence of fibrosis stage is lower (45.3\%) in those with clinically significant fibrosis than in those without. With respect to gender, the grade distribution of hepatic fibrosis was higher in men (47.6\%) than in women (38.2\%) with clinically significant fibrosis.

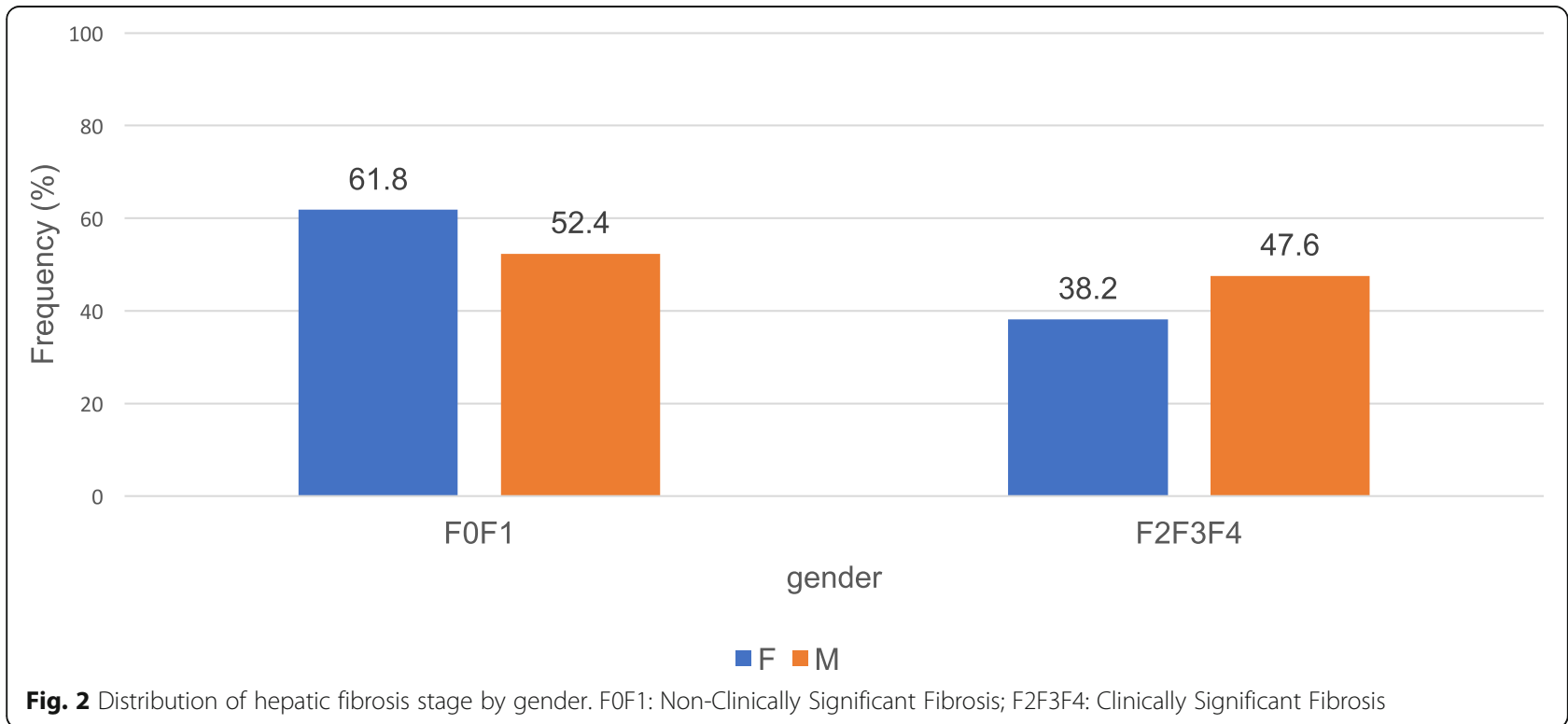


Table 2 Distribution of APRI score by HIV viral load

\begin{tabular}{lllll}
\hline HIV-CV & \multicolumn{4}{l}{$\begin{array}{l}\text { APRI Score } \\
\text { Frequency (\%) }\end{array}$} \\
\cline { 2 - 5 } & F0 & F1 & F3 & F4 \\
\hline Detectable & $0(0.00)$ & $0(0.00)$ & $3(60.00)$ & $2(40.00)$ \\
Undetectable & $3(50.00)$ & $1(16.67)$ & $1(16.67)$ & $1(16.67)$ \\
TOTAL & $\mathbf{3 ( 2 7 . 2 7 )}$ & $\mathbf{1}(\mathbf{9 . 0 9 )}$ & $\mathbf{4}(\mathbf{3 6 . 3 6 )}$ & $3 \mathbf{( 2 7 . 2 7 )}$ \\
\hline
\end{tabular}

Legend: Detectable: Plasmatic HIV viral load $>40$ copies $/ \mathrm{mL}$; Undetectable: Plasmatic HIV viral load $<40$ copies $/ \mathrm{mL}$

\section{Discussion}

Subjects in the over-60 age group were the most infected with $63.6 \%$ of $\mathrm{HIV} / \mathrm{HCV}$ co-infected subjects and $66.3 \%$ of HCV mono-infected subjects. These figures are different from those found in previous studies which found an average age of 48 [45-51] years old [14] and 38 [35-42] years old [15]. Given the silent evolution of HCV infection over several years, these results may be explained by the fact that in our context, screening for $\mathrm{HCV}$ infection is not systematic among high-risk such as HIV infected patients.

Serum aminotransferases (AST and ALT) are critical in the biological evaluation and surveillance of viral hepatitis C. Their increase for more than six-months period is a sign of a transition to chronicity, and 60 to $90 \%$ of chronic hepatitis with elevated transaminases progress to fibrotic liver disease unlike individuals with normal transaminases [10]. We found elevated mean AST level in HIV/HCV co-infected participants compared to $\mathrm{HCV}$ mono-infected $(73.6 \pm 45.8 \mathrm{IU} / \mathrm{L}$ versus $58.5 \pm 39.3 \mathrm{IU} / \mathrm{L})$. The increase in AST levels in our study population when compared to the normal AST value, which ranges between 5 to $40 \mathrm{IU} / \mathrm{L}$ in healthy individuals, could be explained by hepatic cytolysis since the liver is the main target organ for hepatic infections. Moreover, the increase in the rate of AST among HIV/ $\mathrm{HCV}$ co-infected participants could also be linked to the increased replication of HCV-RNA activated by HIV infection; In fact, the interaction between HIV gp120 and CCR5/CXCR4 co-receptors on hepatocytes via TGF- $\beta 1$ which is a key mediator in the process of liver fibrosis as it is one of the most profibrogenic cytokines [9]. Our

Table 3 Distribution of the population by CD4 count and APRI score

\begin{tabular}{|c|c|c|c|c|}
\hline \multirow[t]{2}{*}{$\begin{array}{l}\text { CD4 } \\
\text { count }\end{array}$} & \multicolumn{4}{|c|}{$\begin{array}{l}\text { APRI Score } \\
\text { Frequency n (\%) }\end{array}$} \\
\hline & $\overline{F 0}$ & F1 & F3 & F4 \\
\hline$<200$ & $0(0.00)$ & $0(0.00)$ & $1(33.33)$ & $2(66.67)$ \\
\hline [200-350] & $0(0.00)$ & $0(0.00)$ & $1(100)$ & $0(0.00)$ \\
\hline$>500$ & $3(42.86)$ & $1(14.29)$ & $2(28.57)$ & $1(14.29)$ \\
\hline TOTAL & $3(27.27)$ & 1 (9.09) & $4(36.36)$ & $3(27.27)$ \\
\hline
\end{tabular}

Legend: < 200: Severe immunodepression; [200-350]: Advanced immunodepression; > 500: Immunocompetent results are consistent with a previous study that found that $\mathrm{HIV} / \mathrm{HCV}$ co-infected individuals have a high level of AST ranging from 31 to $75 \mathrm{IU} / \mathrm{L}$. [16].

The mean value of platelets in this study was $172 \pm$ $67 \times 10^{3} \mathrm{IU} / \mathrm{L}$; almost similar to a previous study which found an average of $175 \pm 79 \times 10^{3} \mathrm{IU} / \mathrm{L}$ [16]. The incidence of thrombocytopenia in $\mathrm{HIV} / \mathrm{HCV}$ co-infected participants is $63.6 \%$ as compared to $38.4 \%$ in $\mathrm{HCV}$ mono-infected. This incidence could be explained by the peripheral destruction of platelets due to HIV infection following the existence of antiplatelet autoantibodies specifically directed against certain antigenic determinants of the platelet membrane. The existence of these antiplatelet autoantibodies usually results from a crossreactive humoral reactivity between viral and platelet components, in particular gp120 and gp IIb/IIIa $[17,18]$.

Using the Metavir system, $63.6 \%$ of our study participants co-infected with $\mathrm{HIV} / \mathrm{HCV}$ had clinically significant fibrosis (F2, F3 and F4 stages) as compared to 39.5\% mono-infected. These results are similar to previous studies that found F2, F3 and F4 stages in 59.8\% of $\mathrm{HIV} / \mathrm{HCV}$ co-infected individuals and $46.6 \%$ of monoinfected, respectively $[19,20]$. This high rate of fibrosis is apparently link to the existence of a more active HCV infection supported by HIV-induced $\mathrm{CD}^{+} \mathrm{T}$ cell loss that deregulates $\mathrm{T}$ cell function leading to reduced antifibrotic activity of NK cells, resulting in accelerated progression of liver fibrosis in HIV/HCV co-infected participants [21, 22].

The correlation coefficient ( $r$ ) between the liver fibrosis score and the age of patients in our study population ( $r=0,06$ with $p=0,04)$ shows statistically significant association between the two variables. This result is consistent with a previous study that showed a significant acceleration of hepatic fibrosis after the age of 50 years regardless of the age of infection [23]. Thus, age would be independently associated with the evolution of the liver fibrosis score.

Although the progression of significant fibrosis (F2, F3 and F4) is higher in men (47.6\%) than in women (38.2\%), we did not find a statistically significant association between these two variables $(P=0.11)$. On the other hand, a study has shown that women generally have a slower progression of significant fibrosis than men because estrogen has an inhibitory effect on fibrogenesis [23].

The decrease in CD4 count levels, due to HIV infection, leads to a reduction in the anti-fibrotic activity of NK cells, which leads to rapid progression of hepatic fibrosis in $\mathrm{HIV} / \mathrm{HCV}$ co-infected individuals [9]. The median CD4 count in this study was 536 cells/ $\mu \mathrm{L}$ [IQR: 169-709] which is similar to a previous study that found a median CD4 count of 584 cells/ $\mu \mathrm{L}$ [IQR: $396-775]$ in HIV/HCV co-infection [14]. All study participants (100\%) 
with $\mathrm{CD} 4<200$ cells $/ \mu \mathrm{L}$ had clinically significant fibrosis; therefore, supporting the fact that the decrease in CD4 count levels may activate viral replication $\mathrm{C}$, resulting in increased destruction of liver cells leading to evolution of the fibrosis stage as shown in other studies [9]. The association between the fibrosis score and CD4 count was not statistically significant $(P=0.58)$.

The evolution of HIV infection leads to a strong presence of lipo-saccharide proteins which activate hepatic stellar cells inducing the progression of hepatic fibrosis [10]. Therefore, high viral load can lead to clinically significant fibrosis as exemplified in this study where all participants with detectable HIV viral load had clinically significant fibrosis versus $33.3 \%$ of participants with undetectable viral load; though we did not observe a statistically significant association between liver fibrosis score and HIV viral replication $(P=0,55)$. This result is similar to an earlier study that found no association between HIV viral load and APRI score in individuals co-infected with $\mathrm{HIV} / \mathrm{HCV}$ [14].

\section{Limitations}

Histologic study (liver biopsy) remains the gold standard method to evaluate liver fibrosis stage, unfortunately we were unable to perform it due to lack of funds. We used APRI score to evaluate liver fibrosis in HCV/HIV coinfected patients while it has been widely validated only in HCV mono-infected patients. However, all co-infected participants were on highly active antiretroviral therapy (HAART) which is known to control HIV infection and significantly reduces the impact of HIV in co-infections. It would be interesting in future studies to performed liver biopsy for $\mathrm{HCV}$ mono-infected and co-infected HIV/HCV patients to better set APRI index in both cases.

\section{Conclusion}

The occurrence of higher than normal AST elevation and thrombocytopenia leads to an increased APRI score, a useful tool to stratify the risk of fibrosis progression in $\mathrm{HCV}$ infected individuals. Because of its non-invasive and less costly nature, the APRI score can be used as a biological marker to monitor HIV/HCV co-infected individuals in resource limited settings.

\footnotetext{
Abbreviations

AIDS: Acquired Immune Deficiency Syndrome; APRI: AST/Platelet Ratio Index; CHU: University Teaching Hospital; CIRCB: "Chantal Biya" International Reference Centre; HAART: Highly Active Antiretroviral Therapy; HCV: Hepatitis C Virus; HIV: Human Immunodeficiency Virus; PLWHIV: People Living With HIV; UNAIDS: United Nations Acquired Immune Deficiency Syndrome
}

\section{Acknowledgements}

We thank the "Chantal BIYA" International Reference Center for research on HIV/AIDS prevention and management (CIRCB) for providing reagents, the University Teaching Hospital for providing participants.

\section{Authors' contributions}

Conceived the study: RD, AN, MK, RK, SS, EN, AN and CT. Collected data: RD, AK, MK, and CC. Did biological analyses: RD, AG, FN, RK, SS, AK and CC. Did statistical analysis: RD, CC, AK, SS, AN and CT. Initiated the manuscript: RD, AN, SS and CT. Revised the paper: RD, SS, AN, MK, CT, EN, AN and RK. All the authors have read and approved the final manuscript.

\section{Funding}

The present study was financially supported by the "Chantal BIYA" International Reference Centre for research on HIV/AIDS prevention and management. The funder had no role in the study design, data collection and analysis, and in writing the manuscript of the study findings.

\section{Availability of data and materials}

The datasets used and/or analysed during the current study are available from the corresponding author on reasonable request.

\section{Ethics approval and consent to participate}

Ethical approval for the current study was obtained from the Cameroon National Research Ethics Board for Human Health. Participants provided written informed consent.

\section{Consent for publication}

Not applicable.

Competing interests

The authors declared that, this study is without conflicts of interests.

\section{Author details}

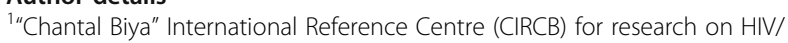
AIDS prevention and management, P.O. Box 3077, Yaoundé, Cameroon. ${ }^{2}$ University of Ngaoundéré, Faculty of Sciences, Ngaoundéré, Cameroon. ${ }^{3}$ University of Yaoundé I, Faculty of Medicine and Biomedical Sciences (FMSB), Yaoundé, Cameroon. ${ }^{4}$ University Teaching Hospital (CHU), Yaoundé, Cameroon. ${ }^{5}$ University of Rome Tor Vergata, Rome, Italy.

Received: 15 July 2020 Accepted: 5 October 2020

Published online: 15 October 2020

\section{References}

1. UNAIDS. 2019 Global HIV Statistics. 2020. https://www.unaids.org/en/ resources/fact-sheet.

2. Aubry PP, Gaüzère B. Infection par le VIH/Sida et tropiques. Mise à jour le 08/07/2018 2018; Source: www.medecinetropicale.com .

3. Organisation. Mondiale de la Sante Rapport mondiale sur I'hepatite, 2017. 2018. http://www.who.int/mediacentre/factsheets/fs164/en/. Accessed 6 Dec 2017.

4. Lavanchy D. Evolving epidemiology of hepatitis C virus. Clin Microbiol Infect. 2011;17(2):107-15 Epub 2010/11/26.

5. Platt L, Easterbrook P, Gower E, McDonald B, Sabin K, McGowan C, et al. Prevalence and burden of HCV co-infection in people living with HIV: a global systematic review and meta-analysis. Lancet Infect Dis. 2016;16(7): 797-808 Epub 2016/02/29.

6. Noubiap JJ, Aka PV, Nanfack AJ, Agyingi LA, Ngai JN, Nyambi PN. Hepatitis B and C co-infections in some HIV-positive populations in Cameroon, west Central Africa: analysis of samples collected over more than a decade. PLoS One. 2015;10(9):e0137375 Epub 2015/09/16.

7. Vallet-Pichard A, Pol S. Natural history and predictors of severity of chronic hepatitis $\mathrm{C}$ virus (HCV) and human immunodeficiency virus (HIV) coinfection. J Hepatol. 2006;44(1 Suppl):S28-34 Epub 2005/12/14.

8. CNLS. Bulletin_epidemiologique_vih_ndeg5.pdf. 2018. 2018. Disponible sur: http://www.cnls.cm/sites/default/files/bulletin_epidemiologique_vih_ ndeg5.pdf.

9. Mastroianni CM, Lichtner M, Mascia C, Zuccala P, Vullo V. Molecular mechanisms of liver fibrosis in HIV/HCV coinfection. Int J Mol Sci. 2014;15(6): 9184-208 Epub 2014/05/29.

10. D. U. Analyse génomique de la coinfection par le virus VIH et VHC (thèse de doctorat). Paris, FRANCE: CNAM; 2016.

11. Wai CT, Greenson JK, Fontana RJ, Kalbfleisch JD, Marrero JA, Conjeevaram $\mathrm{HS}$, et al. A simple noninvasive index can predict both significant fibrosis 
and cirrhosis in patients with chronic hepatitis C. Hepatology. 2003;38(2): 518-26 Epub 2003/07/29.

12. Bedossa P, Poynard T. An algorithm for the grading of activity in chronic hepatitis C. The METAVIR Cooperative Study Group. Hepatology. 1996;24(2): 289-93 Epub 1996/08/01.

13. Myers TW, Gelfand DH. Reverse transcription and DNA amplification by a Thermus thermophilus DNA polymerase. Biochemistry. 1991;30(31):7661-6 Epub 1991/08/06.

14. Gonzalez FA, Van den Eynde E, Perez-Hoyos S, Navarro J, Curran A, Burgos J, et al. Liver stiffness and aspartate aminotransferase levels predict the risk for liver fibrosis progression in hepatitis C virus/HIV-coinfected patients. HIV Med. 2014;16(4):211-8 2014.

15. Sanmartin R, Tor J, Sanvisens A, Lopez JJ, Jou A, Muga R, et al. Progression of liver fibrosis in HIV/hepatitis $C$ virus-coinfected individuals on antiretroviral therapy with early stages of liver fibrosis at baseline. HIV Med. 2014;15(4):203-12 Epub 2013/11/20

16. Merli M, Galli L, Castagna A, Salpietro S, Gianotti N, Messina E, et al: Diagnostic accuracy of APRI, FIB-4 and Forns for the detection of liver cirrhosis in HIV/HCV-coinfected patients. New Microbiol. 2016;39(2): 110-3. 2016

17. Oksenhendler ESM. Thrombopénie immunologique associée à l'infection HIV. Méd Sci. 1989:5(4):220 1989.

18. Nka AD, Sosso SM, Fokam J, Bouba Y, Teto G, Simo Rachel R, et al. Thrombocytopenia according to antiretroviral drug combinations, viremia and CD4 lymphocytes among HIV-infected patients in Cameroon: a snapshot from the City of Yaounde. BMC Res Notes. 2019;12(1):632 Epub 2019/09/27.

19. Benhamou Y, Bochet M, Di Martino V, Charlotte F, Azria F, Coutellier A, et al, Liver fibrosis progression in human immunodeficiency virus and hepatitis $C$ virus coinfected patients. The Multivirc Group. Hepatology. 1999;30(4):10548 Epub 1999/09/25.

20. Yunihastuti E, Wicaksana B, Wiraguna A, Hidayah AJ, Amelia F, Natali V, et al. Diagnostic performance of APRI and FIB-4 for confirming cirrhosis in Indonesian HIV/HCV co-infected patients. BMC Infect Dis. 2020;20(1):372 Epub 2020/05/27.

21. Tian Z, Chen Y, Gao B. Natural killer cells in liver disease. Hepatology. 2013; 57(4):1654-62 Epub 2012/11/01

22. Zhang M, Zhang S. T cells in fibrosis and fibrotic diseases. Front Immunol. 2020:11:1142 Epub 2020/07/18.

23. Poynard T, Ratziu V, Charlotte F, Goodman Z, McHutchison J, Albrecht J. Rates and risk factors of liver fibrosis progression in patients with chronic hepatitis c. J Hepatol. 2001;34(5):730-9 Epub 2001/07/04.

\section{Publisher's Note}

Springer Nature remains neutral with regard to jurisdictional claims in published maps and institutional affiliations.

Ready to submit your research? Choose BMC and benefit from:

- fast, convenient online submission

- thorough peer review by experienced researchers in your field

- rapid publication on acceptance

- support for research data, including large and complex data types

- gold Open Access which fosters wider collaboration and increased citations

- maximum visibility for your research: over $100 \mathrm{M}$ website views per year

At $\mathrm{BMC}$, research is always in progress.

Learn more biomedcentral.com/submissions 